Available online at: https://journals.researchsynergypress.com/index.php/ijmesh

International Journal of Management, Entrepreneurship, Social Science and Humanities

(IJMESH)

ISSN 2580-0981 (online)

Volume 4 Issue 1 (2021): 41-54

\title{
Thy Governance Matters: A Study on Governance Practices of Stock Exchanges in India
}

\author{
Amit Majumder ${ }^{1}$ \\ ${ }^{1}$ Bijoy Krishna Girls' College, Howrah, University of Calcutta, India
}

\begin{abstract}
The governance practices of the apex organizations where the shares of various companies are listed and traded regularly involving trillions of investors with massive funds are always a matter of paramount significance. Historically the responsibility of ushering the practices of good governance, transparent management and effective control process for the corporate house's rests under the jurisdiction of those bourses where the stocks of companies used to get listed. However, the very question of the management and governance of these stock exchange houses are always under the scanner across the globe in view of the limitations of their historic pattern of member-owned 'nonprofit' kind of mutual organizational structure. The lacunae of that typical organizational structure were that their activities are primarily targeted towards members interests as well as that set up was not immune fully from the malice like insider trading and conflict of interest for office bearers and traders. In view of this following the global pattern the Union Government of India had decided for corporatization of stock exchanges thereby creating a separation of ownership, management and trading membership of stock exchanges which is formally known as demutualization and corporatization of stock exchanges. A committee headed by Rev. Justice M.H. Kania which had submitted the report in 2002 recommending corporatizations and demutualization of stock exchanges which become mandatory for every stock exchange in India to implement within a stipulated period of time. Against this backdrop the present study is conducted to make an overview of the present state of governance affairs of major stock exchanges in India. It has been observed that the corporatization and governance practices of the major bourses in India had followed governance practices like separation of the post of chairman and CEO, inclusion of public interest directors as outside directors in the board, adherence to code of conducts for directors, organizing frequent meetings of directors etc.
\end{abstract}

Keywords: Governance; Demutualization; Corporatization; Board Structure.

This is an open access article under the CC-BY-NC license

\section{INTRODUCTION}

Historically the responsibility of ushering the practices of good governance, transparent management and effective control process for the corporate house's rests under the jurisdiction of those bourses where the stocks of companies used to get listed. However, very question of the management and governance of these stock exchange houses are always under the scanner across the globe in view of the limitations of their historic pattern of member-owned 'non-profit' kind of mutual organizational structure. Moreover, governance practices of the apex organizations where the shares of various companies are listed and traded regularly involving trillions of investors with massive funds are always a matter of paramount significance. Against this backdrop present study

Corresponding author:

amitmajumder1@gmail.com

DOI: https://doi.org/10.31098/ijmesh.v4i1.525

Research Synergy Foundation 
International Journal of Management, Entrepreneurship, Social Science and Humanities (IJMESH), Vol. 4 (1), 41-54

Thy Governance Matters: A Study on Governance Practices of Stock Exchanges in India

Amit Majumder

is envisaged to observe the governance practices of the major stock exchanges operating in India against various parameters of good governances.

\section{LITERATURE REVIEW}

A few significant studies are conducted to observe the governance practices of stock exchanges in global basis in general and in India in particular. A few of such important studies are as follows.

Grimminger and Benedetta (2013) had made a study under the aegis of IFC and World Bank on indices of eight major stock exchanges in the World like Brazil BM\&F Bovespa, Shanghai Stock Exchange (SSE) of China, Borsa Italiana of Italy, Mexican Stock Exchange (BMV), Lima Stock Exchange (BVL) of Peru, Johannesburg Stock Exchange (JSE) of South Africa, Korea Stock Exchange (KRX) of South Korea and Istanbul Stock Exchange (ISE) of Turkey. It has been observed that Corporate Governance Indices of Brazil BM\&F Bovespa outperformed the market overtime.

Ching and Tardelli (2015) had made a comparative study on the corporate governance practices of six stock exchanges namely Tokyo TSE, New York NYSE, Frankfurt Stock Exchange, Brazil BM\&F Bovespa, London Stock Exchange and Toronto TSX. He found London Stock Exchange fared top with compliance of 12 out of 15 rules of Corporate Governance and TSX is the least compliant.

However, no significant study on the governance practices of Indian stock exchanges is conducted till now which had drawn the attention of the researcher to fill up this gap.

\section{Basic Architecture of Stock Exchanges:}

Basically, stock exchanges are constructed in the form of member-owned 'non-profit' kind of mutual organizational structure. However, the lacunae of that typical organizational structure were that their activities are primarily targeted towards members interests as well as that set up was not immune fully from the malice like insider trading and conflict of interest for office bearers and traders.

\section{Corporatization and Demutualization of Stock Exchanges:}

In view of this following the global pattern the Union Government of India had decided for corporatization of stock exchanges thereby creating a separation of ownership, management and trading membership of stock exchanges which is formally known as demutualization and corporatization of stock exchanges.

\section{Stock Exchanges Demutualization:}

Stock Exchanges Demutualization is defined as the mechanism of reconstructing a nonprofit member-owned mutualized entity into a for-profit corporation with participation of shareholders. Here the stock exchanges used to change their institutional structures into profitoriented organizational structures. Stockholm Stock Exchange was the first stock exchange of the World to get demutualized and became the trend setter of demutualization process of stock exchanges since 1993. Since then, 23 stock and derivative exchanges became publicly listed corporations (August, 2012). 


\section{Reasons for Demutualization of Stock Exchanges:}

(1) Increased global competition:-One of the major reasons in the decisions of exchanges to get demutualized is the increased competition among the stock exchanges both at regional as well as international level. The bourses had realized rapidly that Stock they cannot become regionally myopic in their region and in order to increase efficiency, recognition and performance they have no other alternative but to go for demutualization.

(2) Technology and the rise of "Electronic Communication Networks (ECNs)":- In the advent of technological deluge and emergence of alternative machine-based trading systems the bourses have to adopt real-time settlement-based trading systems and to promptly migrate to the electronic trading system.

(3) Conflicts of interest among existing owners:- Since the markets become more sophisticated and the different interests of various groups started to diverge it creates tremendous pressure in traditional governance and the decision-making process of stock exchanges thereby creating a direct pressure to them towards moving for demutualization (Aggarwal and Dahiya, 2005).

Figure 1. Process of Demutualization of Stock Exchange

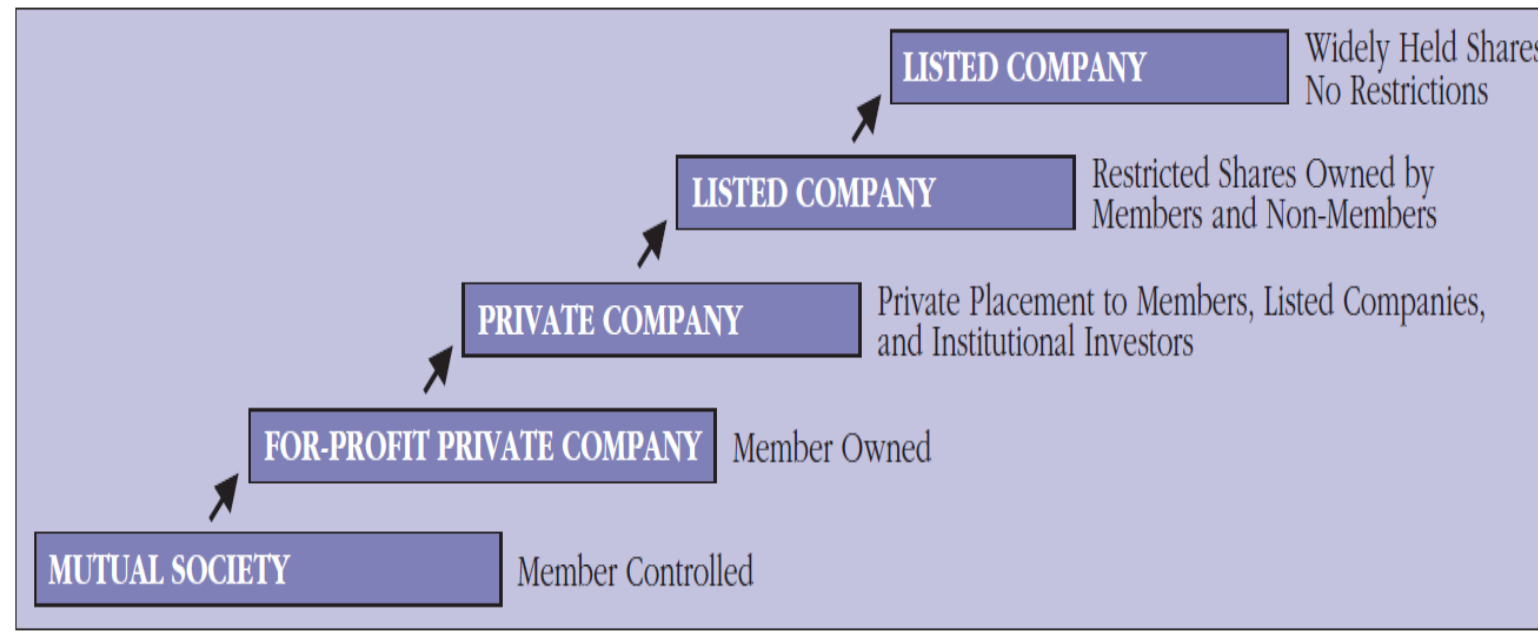

Process of Demutualization of Stock Exchange

\section{Various Forms off Demutualized Stock Exchange:}

There are three forms of demutualized stock exchanges like

(i) Demutualized Publicly Listed Company formed Stock Exchange

(ii) Demutualized and Publicly Listed Company in own exchanges

(iii) Demutualized \& Subsidiary of Publicly traded holding co

(iv) Process of Demutualization of Stock Exchange

Various Forms off Demutualized Stock Exchange:

There are three forms of demutualized stock exchanges like

(i) Demutualized Publicly Listed Company formed Stock Exchange

(ii) Demutualized and Publicly Listed Company in own exchanges

(iii) Demutualized \& Subsidiary of Publicly traded holding co 
Figure 2. Forms of demutualized stock exchanges

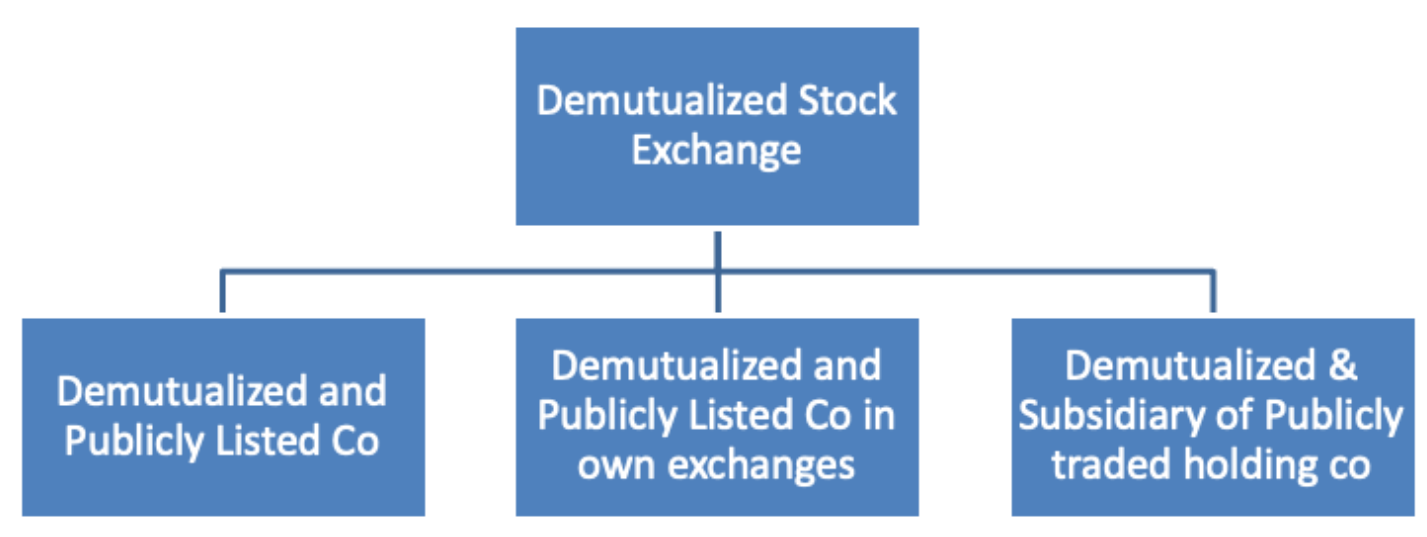

Table 1. Legal Status and Demutualization of Stock Exchanges across the globe:

\begin{tabular}{|l|l|l|}
\hline Name of the Stock Exchange & The Legal Status & Year of Demutualization \\
\hline The Athens Stock Exchange & Public listed co & 1999 \\
\hline Australian Securities Exchange & Public listed co & 1998 \\
\hline BM\&FBOVESPA S.A. & Public listed co & 2007 \\
\hline BME Spanish Exchanges & Public listed co & 2001 \\
\hline Bolsa de Valores de Colombia & Public listed co & 2001 \\
\hline Bursa Malaysia & Public listed co & 2004 \\
\hline The Deutsche Börse & Public listed co & 2000 \\
\hline The Hong Kong Exchanges and Clearing & Public listed co & 2000 \\
\hline The Johannesburg Stock Exchange & Public listed co & 2005 \\
\hline The London Stock Exchange Group & Public listed co & 2000 \\
\hline NASDAQ OMX & Public listed co & 2008 \\
\hline NYSE Euronext & Public listed co & 2007 \\
\hline Philippines Stock Exchange & Public listed co & 2001 \\
\hline
\end{tabular}


International Journal of Management, Entrepreneurship, Social Science and Humanities (IJMESH), Vol. 4 (1), 41-54 Thy Governance Matters: A Study on Governance Practices of Stock Exchanges in India

Amit Majumder

\begin{tabular}{|l|l|l|}
\hline Singapore Stock exchange & Public listed co & 1999 \\
\hline Warsaw Stock Exchange & Public listed co & 2010 \\
\hline Bucharest stockexchange & Public listed co & 2010 \\
\hline
\end{tabular}

Table 2. Demutualized but not Listed of Stock Exchanges across the globe:

\begin{tabular}{|c|c|c|}
\hline Stock Exchange & Legal Status & $\begin{array}{l}\text { Year of } \\
\text { Demutualization }\end{array}$ \\
\hline The Bermuda stock Exchange & $\begin{array}{l}\text { Demutualized but not } \\
\text { listed co }\end{array}$ & 1992 \\
\hline $\begin{array}{l}\text { The Bombay stock exchange } \\
\text { (BSE) }\end{array}$ & $\begin{array}{l}\text { Demutualized but not } \\
\text { listed co }\end{array}$ & 2005 \\
\hline The Budapest stock exchange & $\begin{array}{l}\text { Demutualized but not } \\
\text { listed co }\end{array}$ & 2002 \\
\hline Korea Stock exchange & $\begin{array}{l}\text { Demutualized but not } \\
\text { listed co }\end{array}$ & 2005 \\
\hline Malta stock exchange & $\begin{array}{l}\text { Demutualized but not } \\
\text { listed co }\end{array}$ & 2007 \\
\hline $\begin{array}{l}\text { The National stock exchange of } \\
\text { India (NSE) }\end{array}$ & $\begin{array}{l}\text { Demutualized but not } \\
\text { listed co }\end{array}$ & 1993 \\
\hline Oslo bors & $\begin{array}{l}\text { Demutualized but not } \\
\text { listed co }\end{array}$ & 2001 \\
\hline SIX Swiss exchange & $\begin{array}{l}\text { Demutualized but not } \\
\text { listed co }\end{array}$ & 2002 \\
\hline $\begin{array}{l}\text { The Stock exchange of } \\
\text { Mauritius }\end{array}$ & $\begin{array}{l}\text { Demutualized but not } \\
\text { listed co }\end{array}$ & 2008 \\
\hline Stock Exchange of Tehran & $\begin{array}{l}\text { Demutualized but not } \\
\text { listed co }\end{array}$ & 2006 \\
\hline Taiwan stock exchange & $\begin{array}{l}\text { Demutualized but not } \\
\text { listed co }\end{array}$ & 1961 \\
\hline $\begin{array}{l}\text { Tokyo stock exchange Group } \\
\text { Inc. }\end{array}$ & $\begin{array}{l}\text { Demutualized but not } \\
\text { listed co }\end{array}$ & 2001 \\
\hline
\end{tabular}


Table 3. Stock Exchanges across the globe as Private Ltd Company:

\begin{tabular}{|l|l|l|}
\hline Stock Exchange & Legal Status & $\begin{array}{l}\text { Year of } \\
\text { Demutualization }\end{array}$ \\
\hline Bourse de Casablanca & Private Limited Co & - \\
\hline Bourse de Luxemburg & Private Limited Co & - \\
\hline Indonesia stock exchange & Private Limited Co & - \\
\hline Irish stock exchange & Private Limited Co & - \\
\hline Tel Aviv stock exchange & Private Limited Co \\
\hline Wiener Börse AG & Private Limited Co \\
\hline
\end{tabular}

Table 4. The stock exchanges across the globe as different legal status:

\begin{tabular}{|l|l|l|}
\hline Stock Exchange & Legal Status & $\begin{array}{l}\text { Year of } \\
\text { Demutualization }\end{array}$ \\
\hline Bolsa de Comercio de Buenos Aires & Association & - \\
\hline The Shanghai stock exchange & Association & - \\
\hline Shenzhen stock exchange & Association & - \\
\hline Amman stock exchange & Other legal status & - \\
\hline Colombo stock exchange & Other legal status & - \\
\hline Cyprus stock exchange & Other legal status & - \\
\hline
\end{tabular}




\begin{tabular}{|l|l|}
\hline Moscow Interbank Currency Exchange & Other legal status \\
\hline Saudi stock exchange & Other legal status \\
\hline Stock exchange of Thailand & Other legal status \\
\hline Egyptian exchange & Other legal status \\
\hline
\end{tabular}

\section{Kania Committee Recommendations:}

A committee was set up by the SEBI headed by Rev Justice M.H. Kania which had submitted the report on August, 2002 recommending corporatizations and demutualization of stock exchanges which become mandatory for every stock exchange in India to implement within a stipulated period of time.

\section{Few Salient Recommendations-}

a) bourses which are established as the association of persons and those set up as companies that are limited by guarantee should be converted into companies limited by the shares;

b) adoption of common model for corporatization as well as demutualization should be considered for all bourses; and

c) relevant amendment should be undertaken on various legal provisions like the Income Tax Act, Securities Contracts (Regulation) Act, Indian Stamp Act etc. to pave the way for corporatization and demutualization of the bourses.

\section{Governance of Stock Exchanges as per Kania Committee Report:}

a) In the governing board of the demutualized exchange three stakeholders should equally represent shareholders, brokers and investing public;

b) In the board there should be specific vacancies for each group of stakeholders;

c) Shareholders' representatives should not be functioning brokers;

d) Broker's representatives should be elected by the shareholders among the brokers of exchange;

e) Representatives of investing public should be nominated by the Securities and Exchange Board of India (SEBI)from among a panel consisting of academics, professionals, industry representatives, public figures and investor associations, none of whom should have any interest in any broking firm;

f) Shareholders should be provided adequate disclosures on background of all members of board of directors at annual general meetings (AGM) as well as the same should be disclosed in the annual report;

g) What should be the maximum number of allowed directors in the board that should be guided by the relevant provisions of the Companies Act. 
h) It is also prescribed that there should be separation in the post of Chairmanship and CEO and the Chairperson should have considerable knowledge and experience regarding functionality of the stock exchanges and the mechanism of the capital market,

i) Chairperson of the Board of Directors of the Stock Exchanges should not be a practicing broker,

j) Relevant norms that are applicable for listed companies will also be equally applicable for the stock exchanges as per the relevant provisions of the Companies Act. Some norms in this respect are constitution of various board committees like audit committee, nomination \& remuneration committee, stakeholders relationship committee, corporate social responsibility committee etc., adherence to standards of financial disclosure, disclosures in annual reports, management discussion and analysis etc.;

k) Stock Exchanges must recruit a Chief Executive Officer (CEO) responsible for daily functioning of bourse as well as risk management policies and legal compliances

l) However, appointment of Chief Financial Officer (CFO) is optional for the stock exchanges

m) Board of directors of stock exchange must be aware about the fact that it should not constitute any board committee that would create dilution of independence of CEO of the exchange and day to day operation of the

n) n)The Committee recommended that Kania the demutualized stock exchange may list their shares on itself or any other stock exchange. If the stock exchange is listed then the monitoring of its listing conditions should lie to Central Listing Authority or Securities and Exchange Board of India (SEBI) as per the pattern followed in international context like in UK and Australia.

\section{Objective of Study}

Present study is a desk-based study conducted to make an overview of the present state of governance affairs of major stock exchanges in India.

\section{METHODOLOGY}

In order to observe the corporatization and demutualization efforts along with present state of governance affairs of major stock exchanges in India a few premiere stock exchanges of India have been selected namely-

- Bombay Stock Exchange (BSE),

- National Stock Exchange (NSE),

- Calcutta Stock Exchange (CSE),

- Ahmedabad Stock Exchange Ltd,

- Cochin Stock Exchange

- Pune Stock Exchange (PSE),

- Inter connected Stock Exchange of India (ISE)

- OTC exchange of India (OTCEI),

- Multi Commodity exchange of India (MCX),

- National Commodity \& Derivative exchange (NCDEX). 
The annual reports of these selected Indian stock exchanges as well as the corporate disclosure practices regarding various parameters of good governance as disclosed in website and printed materials are consulted to observe the governance performance of these selected stock exchanges in India. The most recent published data i.e., 2020-21 are used for this purpose.

\section{FINDINGS}

1) Governance Structure of Bombay Stock Exchange (BSE) (Estd 1875).

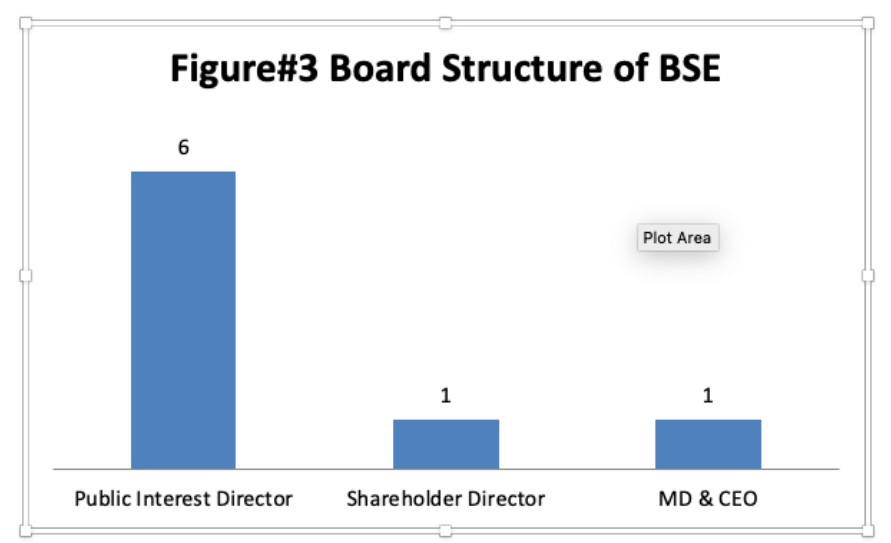

Source: Computed by the Researcher from current published data, 2020-21

It appears from the above chart that the board structures of BSE are well diversified well with representation from various status like Public Interest Director (75\%) and Shareholder Director (12.5\%). Moreover, the board of BSE is also gender diversified with one woman director in board. The position of Chairmanship and Management Directorship are separated in order to avoid concentration of power in single hand and invitation of alternative thoughts.

\section{2) Governance Structure of National Stock Exchange (NSE) (Estd: November,1992)}

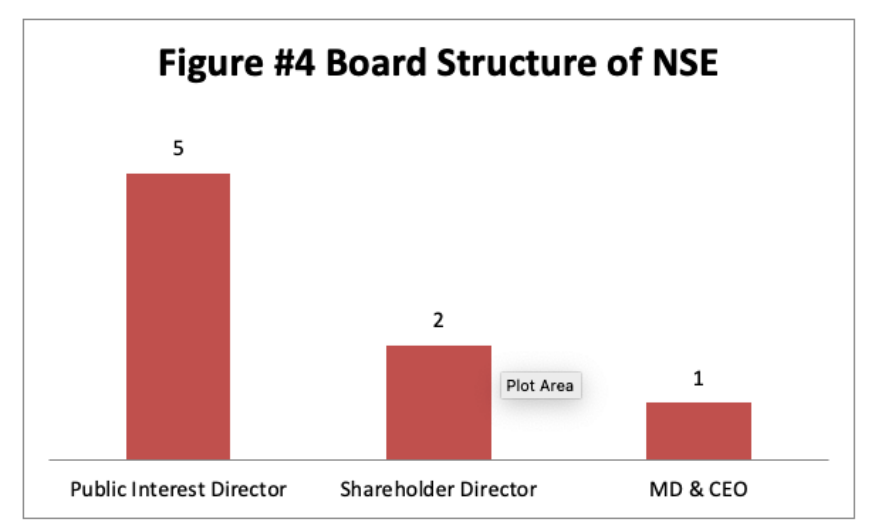

Source: Computed by the Researcher from current published data, 2020-21

It appears from the above chart that the board structures of NSE is well diversified well with representation from various status like Public Interest Director (62.5\%) and Shareholder 
Director (25\%). Moreover, the board of NSE is also well gender diversified with two women directors in board. The position of Chairmanship and Management Directorship are separated in order to avoid concentration of power in single hand and invitation of alternative thoughts.

\section{3) Governance Structure of Calcutta Stock Exchange (CSE) (Estd: November 1908)}

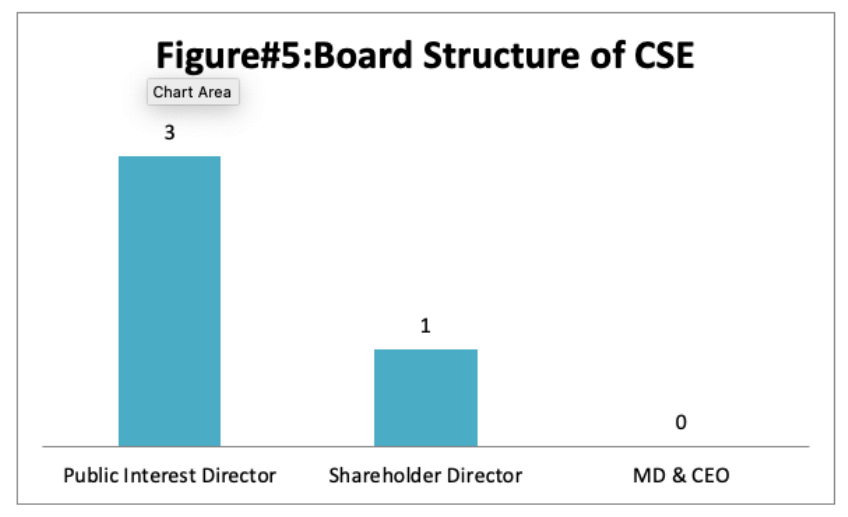

Source: Computed by the Researcher from current published data, 2020-21

It appears from the above chart that the board structures of CSE is diversified with representation from various status like Public Interest Director (75\%) and Shareholder Director (25\%). However, the CSE has no position of MD \&CEO. Moreover, the CSE has no women representation on board.

\section{4) Governance Structure of Ahmedabad Stock Exchange Ltd (ASE) (Estd: November, 1894)}

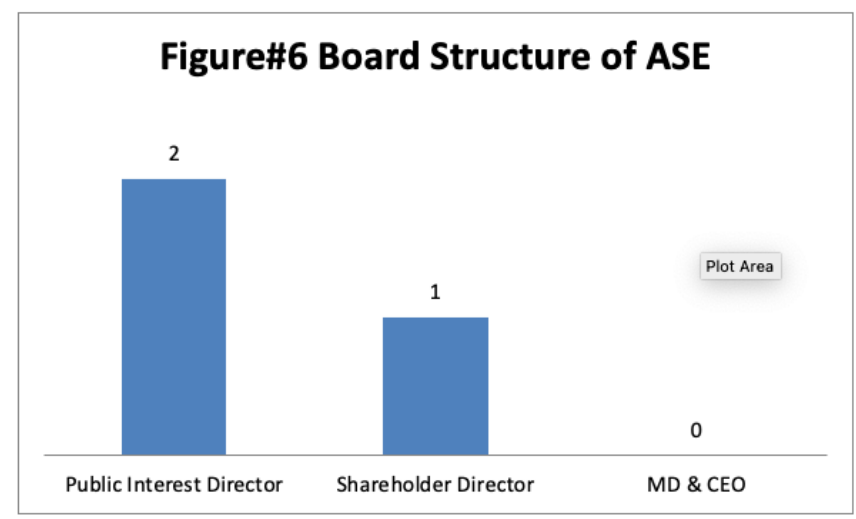

Source: Computed by the Researcher from current published data, 2020-21

It appears from the above chart that the board structures of ASE are diversified with representation from various status like Public Interest Director (66.67\%) and Shareholder Director (33.33\%). However, the ASE has no position of MD \&CEO. Moreover, the ASE has no women representation on board. 


\section{5) Governance Structure of Pune Stock Exchange (PSE) (Estd: November, 1982)}

By virtue of SEBI Order vide $7^{\text {th }}$ April, 2003 observing the irregularities in PSE, SEBI had issued an order u/s 11 of the Securities Contracts (Regulation) Act, 1956 superseded the Board of Directors of Pune Stock Exchange Lts and had appointed Mr. B.D. Banerjee as the Administrator of the Exchange to exercise and perform all the power and duties of the Board.

\section{6) Governance Structure of Cochin Stock Exchange (CSE) (Estd: November, 1978)}

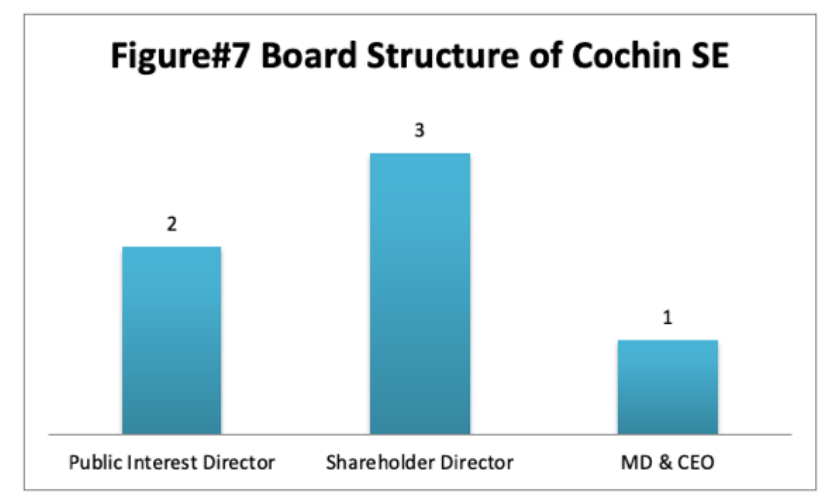

Source: Computed by the Researcher from current published data, 2020-21

It appears from the above chart that the board structures of Cochin SE are well diversified well with representation from various status like Public Interest Director (33.33\%) and Shareholder Director (50\%). Moreover, the board of Cochin SE is also gender diversified with onewoman directors in board.

\section{7) Governance Structure of Inter-Connected Stock Exchange of India (ISE) (Estd: November,} 1998)

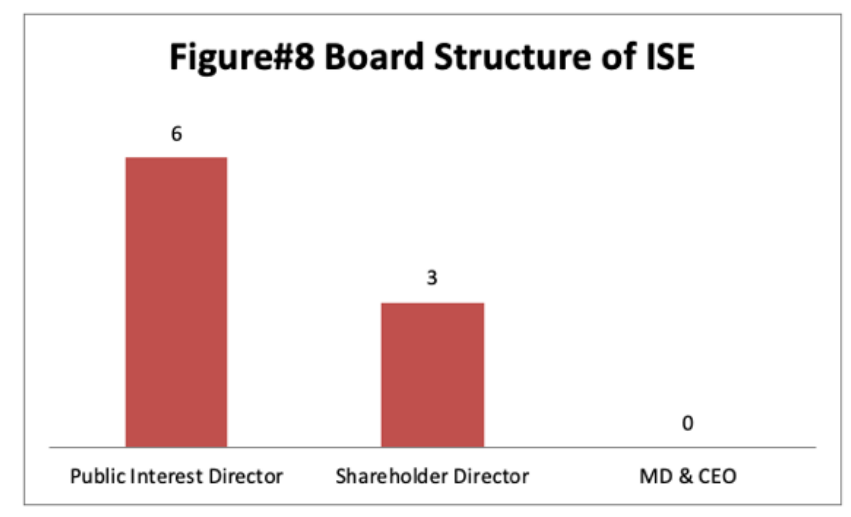

Source: Computed by the Researcher from current published data, 2020-21

It appears from the above chart that the board structures of ISE are diversified with representation from various status like Public Interest Director (66.67\%) and Shareholder Director (33.33\%). However, the ISE has no women representation on board. 


\section{8) Governance Structure of OTC Exchange of India (OTCEI) (Estd: November, 1990)}

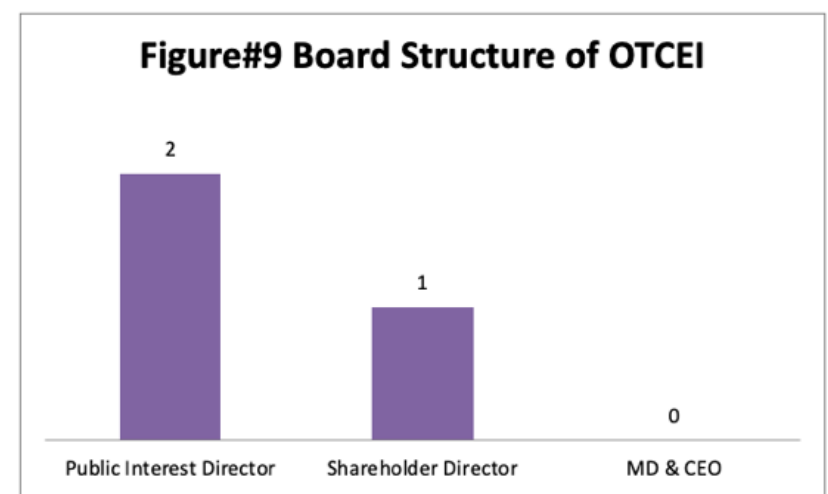

Source: Computed by the Researcher from current published data, 2020-21

It appears from the above chart that the board structures of OTCEI is diversified with representation from various status like Public Interest Director (66.67\%) and Shareholder Director (33.33\%). However, the OTCEI has no women representation on board.

9) Governance Structure of Multi Commodity Exchange of India (MCX) (Estd: November, 2003)

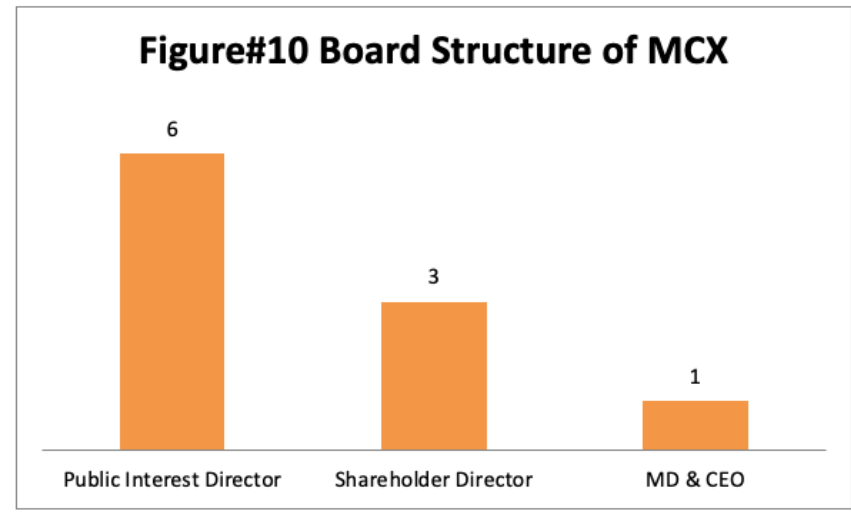

Source: Computed by the Researcher from current published data, 2020-21

It appears from the above chart that the board structures of MCX is well diversified well with representation from various status like Public Interest Director (60\%) and Shareholder Director (30\%). Moreover, the board of MCX is also well gender diversified with two women directors in board. The position of Chairmanship and Management Directorship are separated in order to avoid concentration of power in single hand and invitation of alternative thoughts. 
10) Governance Structure of National Commodity and Derivatives Exchange Limited (NCDEX)

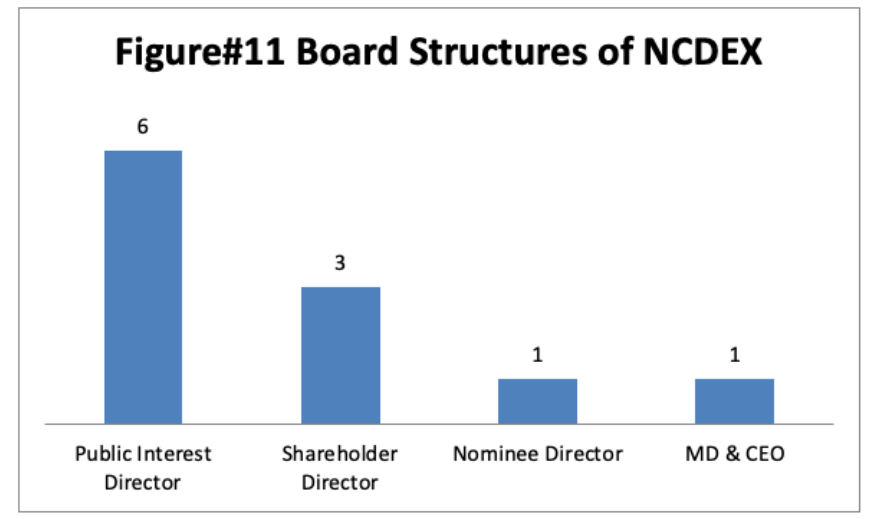

Source: Computed by the Researcher from current published data, 2020-21 (Estd: November 2003)

It appears from the above chart that the board structures of NCDEX is well diversified well with representation from various status like Public Interest Director (54.54\%), Shareholder Director (27.27\%) and one nominee director as advisor to financial institution. Moreover, the board of NCDEX is also gender diversified with one-woman directors in board. The position of Chairmanship and Management Directorship are separated in order to avoid concentration of power in single hand and invitation of alternative thoughts.

Mandatory Board Committees followed by Majority of the Stock Exchanges in India:

(i) The Membership Selection Committee

(ii) The Disciplinary Action Committee

(iii) The Investor Grievance Redressal Committee

(iv) The Defaulters' Committee

(v) The Compensation Committee

(vi) The Standing committee on Technology

(vii) Sub-Committee for Monitoring Compliance of suggestions given in SEBI Inspection Report

(viii) The Investor Services Committee

(ix) The Public Interest Directors' Committee

(x) The Arbitration Committee

(xi) The Ethics Committee

(xii) Independent Oversight Committee for Member Regulation

(xiii) Independent Oversight Committee for Listing Function

(xiv) Independent Oversight Committee for Trading and Surveillance Function

(xv) The Advisory Committee

\section{CONCLUSION}

It has been observed that the corporatization and governance practices of the major bourses in India had followed governance practices like separation of the post of chairman and CEO, 
inclusion of public interest directors as outside directors in the board, adherence to code of conducts for directors, organizing frequent meetings of directors, inclusion of women directors etc. However, the issues of mismanagement and poor governance structures also badly hit various stock exchanges in India like CSE, ASE, PSE, OTCEI etc. which either going for liquidation or administered directly by SEBI after dissolving the board by virtue of their notification. These factors are not at all promising all together and a few dominating stock exchanges in India like BSE, NSE, MCX, NCDEX are moving in right direction thanks to good governance mechanisms well directed by their efficient well diversified board with strong management acumen and dedicated controlling mechanism for protecting the best interests of all stakeholders connected with the exchanges.

\section{REFERENCES}

Aggarwal R., (2002) Demutualization and corporate governance of stock exchanges, Journal of Applied Corporate Finance, 15(1),105-113

Aggarwal R., Dahiya S., (2005) Demutualization and public offerings of financial exchanges, available online at http://faculty.msb.edu/aggarwal/exchanges.pdf, accessed on 05.05.2021, 1-25

Ching, H.Y. and Tardelli, R., (2015) Corporate governance rules in six stock exchanges: A comparative study, Advances in Social Research Science Journal, 2(2),197-209

Grimminger, A.D. and Benedetta, P.D. (2013) Raising the bar on corporate governance: A study of eight stock exchanges indices, The World Bank and International Finance Corporation, https://www.ifc.org/wps/wcm/connect/15731a82-572f-4301-9b63e7b2889498d1/Raising_the_bar_on_CG.pdf?MOD=AJPERES\&CVID=jZp9q5C, accessed on 26.06.2021

Krishnamurti C., Sequeira J.M. and Fangjian F., (2003) Stock exchange governance and market quality, Journal of Banking and Finance, 27, 1859-78

Lee R., (2002) Changing market structures, demutualization and the future of securities trading, available online at http://www.oecd.org/finance/financialmarkets/18450470.pdf, accessed on 23.04.2021, 1-20 